\title{
ENGINEERING EDUCATION IN A TECHNOLOGY-DEPENDENT WORLD
}

\author{
Claudio da Rocha Brito ${ }^{1}$,Melany M. Ciampi ${ }^{2}$,Rosa Vasconcelos $^{3}$, Luis Amaral ${ }^{4}$, Muthar Al-Ubaidi $^{5}$
}

\begin{abstract}
Education is the core of any nation development, of a community or personal. It is for sure a society that is depending on technology for deployment of information, communication, and network in real time. In a short period of time, social technologies have given social interactions the speed and scale of the Internet. It affects the way people work, live and make business. This work intends just to show a little of INTERTECH an event that is happening for more than 24 years and its contributions for engineering and technology education. An endeavor of manyscientists in order to provide a breeding ground for discussions about engineering and technology education so important aspects for the formation of professionals and researchers prepared to face the future. The theme of the congress is Engineering Education in a Technology-Dependent World and it has raised a considerable amount of papers of great valuable.
\end{abstract}

Index Terms -congress, engineering, social technology, challenging environment.

\section{INTRODUCTION}

Along its existence INTERTECH has provided a forum for the discussions about the engineering and technology education mainly in Americas where it has a wide range of institutions and professionals who have contributed for these discussions. With its evolution it became a world organization becoming International Council for Engineering and Technology.

The International Council for Engineering and Technology -INTERTECH consists of scientists of engineering and technology areas, who believe in the development of science and technology as promoters of humanity welfare. The members belong to the several countries of North America, Europe and Latin America. The Council headquarter is in Cincinnati, Ohio in United States of America.

It is a council, which works has the objective to foster and keep the relationship between University and Educational Institutions, the enterprises and society of the several countries, for the discussions about the future of science and technology. Its activities have contributed to the discussions and promotion of education worldwide under the challenging managerial environment of present world.

Due to its international members it can provide the academic community a wide range of actions and researches for the promotion of engineering and technology education. Its proposal is "to educate for future" because today is already now and yesterday is over [1-3].

\section{HISTORY}

INTERTECH - International Council for Engineering and Technology has a history that can be traced back in 1989, when scientists and researchers from USA and Mexico created it. From the first conference of 1990 (Mexico), 1992 (USA), 1994 (Brazil), 1996 (Venezuela), 1998 (Brazil), 2000 (USA), 2002 (Brazil), 2004 (Bahamas), 2006 (USA), 2008 (Brazil), 2010 (Brazil)2012 (East Timor) planning activities in 1991,1993, 1995, 1997, 1999, 2001, 2003, 2005, 2007, 2009,2011 and 2013 [4-11].

Long before the discussions about globalization INTERTECH has been working to encourage and promote efforts to bring an international perspective for engineering and technology institutions, as well as to establish and maintain relationship between engineering and technology educators and institutions in countries throughout the world.

The $7^{\text {th }}$. Edition of INTERTECH, in 2002 was organized by COPEC, in São Vicente, Brazil. In 2004 it was back to north hemisphere. The $10^{\text {th }}$ edition of INTERTECH conference was in 2008, in the Atlantic Forest Coast, in Brazil, organized by COPEC - Science and Education Research Counciland hosted by Catholic University of Santos. It had many participants from different Countries, from the 5 continents. Since then COPEC is in charge of organizing the congresses INTERTECH. In 2010 INTERTECH wasorganized in Ilhéus, in Bahiastate, Brazil, where it has been always welcome and found a Brazilian audience that considers it a traditional conference that has brought many valuable contributions for the fostering of engineering education in the Country once it congregates the national and international professionals debating the latest topics of engineering and technology education. In 2012 INTERTECH was in Australasia for the first time, in Dili,

\footnotetext{
${ }^{1}$ Claudio da Rocha Brito, President of COPEC - Science and Education Research Council and Vice President of INTERTECH - International Council for Engineering and Technology Education, RuaFrei Gaspar, 931, room 86, 11.310-061, São Vicente, SP, Brazil, cdrbrito@ copec.org.br

${ }^{2}$ Melany M. Ciampi, President of SHERO - Safety, Health and Environment Research Organizationand Vice President of IGIP - International Society for Engineering Education, Rua Gil Vicente, 18, Nogueira, 4715-193, Braga, Portugal, melany @ copec.org.br

${ }^{3}$ Rosa Vasconcelos, Vice President of School of Engineering of University of Minho, Guimarães, Portugal, rosa @ det.uminho.pt

${ }^{4}$ Luis Amaral, President of CCG - Computer Graphics Center of University of Minho, Guimarães, Portugal, amaral@ dsi.uminho.pt

${ }^{5}$ Muthar Al-Ubaidi, President of INTERTECH - International Council for Engineering and Technology Education, Cincinnati, OH, USA, muthar.alubaidi@uc.edu
} 
East Timor with a massive participation of teachers, researchers and students of East Timor.

In 2014 it happens in Guimarães, Portugal, an amazing historical city hosted by the University of Minho and Computer Graphics Center, two organizations top in Europe.

Just to have an idea of the distribution of participants during INTERTECH in Brazil. The event had 347 participants from all the regions of Brazil and from abroad. It had 260 papers peer reviewed covering a wide range of topics, in 42 technical sessions and 3 Plenary Sessions. It was considered participants only those who had registered in the event. However the number of people that were present was more than the double. Figures 1, 2 and 3 show the distribution of participants by regions in Brazil and from other Countries.

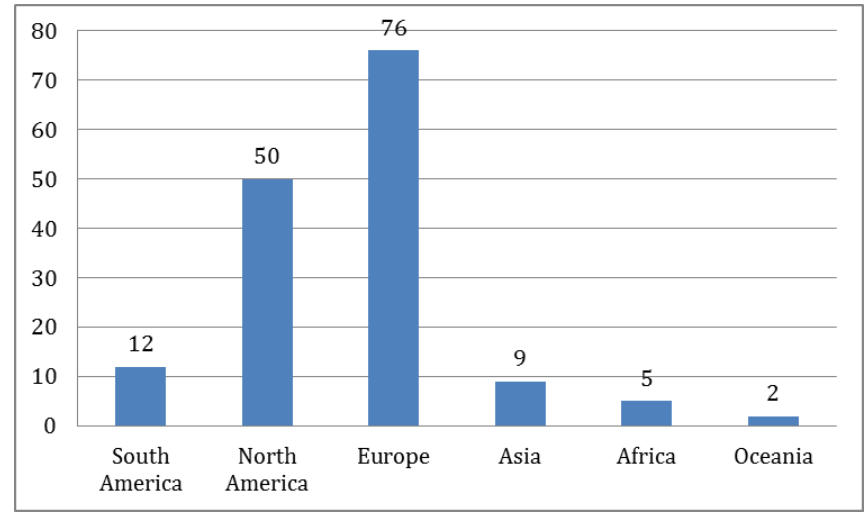

Fig. 1

Participantsfromother Countries (exceptBrazil)

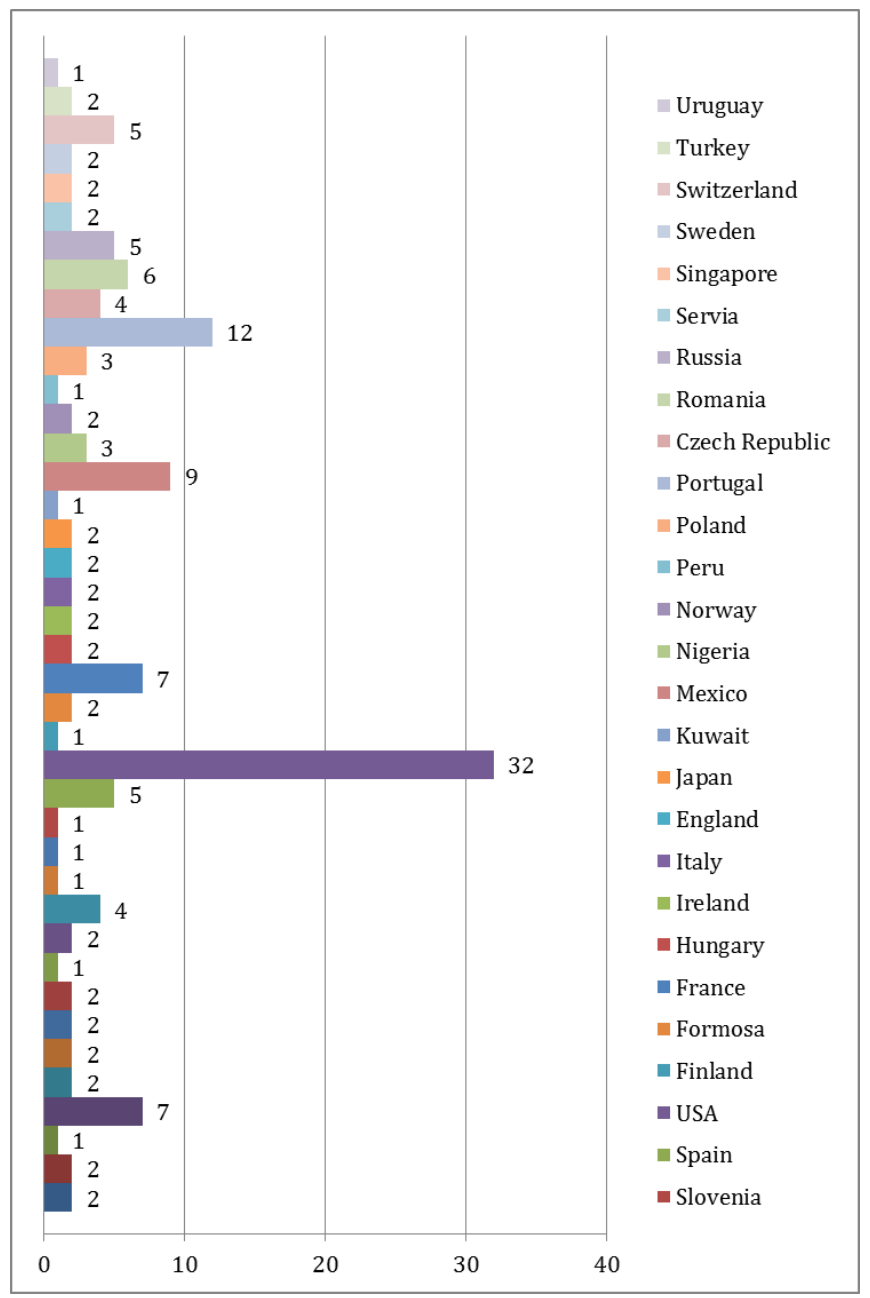

Fig. 3

Participantsfrom other continents (except Brazil)

\section{INTERTECH'2014}

The XIII International Conference on Engineering and Technology Education INTERTECH'2014 takes place in Guimarães, Portugal. A city full of history and culture, Guimarães is a city of considerable significance by virtue of the fact that specialized building

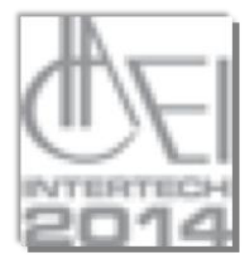
techniques developed there in the Middle Ages were transmitted to Portuguese colonies in Africa and the New

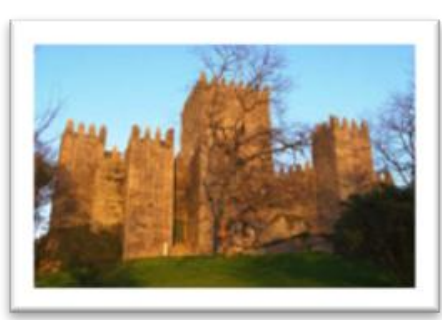

World, becoming their characteristic feature. It is an exceptionally wellpreserved town illustrating the evolution of particular building types from the medieval settlement to the presentday and particularly in 
the $15^{\text {th }}$ to $19^{\text {th }}$ centuries [12-13].

It is unanimously agreed upon that the name and image attributed to the Historic City Centre of Guimarães has spilled over into the arena of public domain, taking with it the ever-present concept of quality rightfully associated with the City Centre. Over many years, Guimarães city officials pursued a policy of preserving architectural forms and rededicating spaces to new functions such that old and forgotten areas of the city were given a rebirth. Guimarães is the focus of greater levels of interest and recognition, both nationally and internationally, as a result of the city's strong commitment to the criteria it adopted and craftsmanship it supported in this area.

On the 13th of December 2001, UNESCO granted the Historic City Centre of Guimarães the distinction of "World Heritage Site"

- on the basis of the its strong link to the people

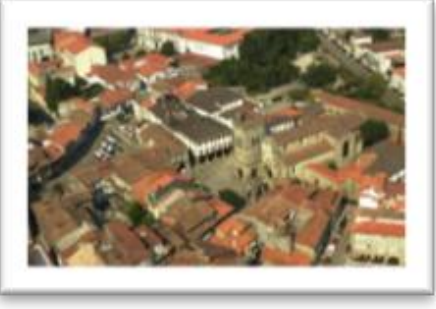
and events involved in founding of the Portuguese Nation, - due to the fact that architectural techniques developed there in the Middle Ages were then spread throughout the country, and

- in view of the evolution of various types of construction present in Guimarães, notably examples from the 15th to the 19th centuries.

The Couros Multi-Purpose Complex, which came into being following the renovation of an urban zone known for the leatherworking trade, the neighborhood of Couros. The complex is made up of:

The Youth Hostel

The Guimarães Cyber Centre

The Social Solidarity Centre

The Youth Support Centre

The Leatherworking Museum (under construction)

The congress is accomplished with the partnership of two top European institutions, the UMINHO - University of Minho and CCG - Computer Graphic Center [14-15].

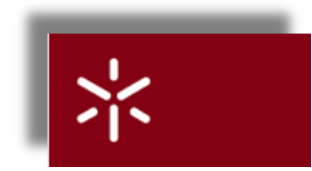

The University of Minho is currently among the most prestigious institutions of higher education in the country, and it has also gradually come to assert itself on the international scene. Founded in 1973, the University has two major poles: the campus of Gualtar in Braga, and the campus of Azurém in Guimarães.

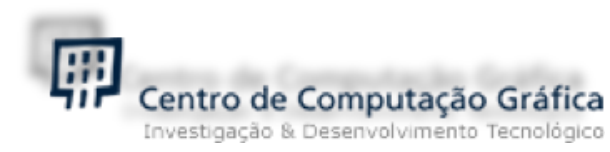

The Association CCG/ZGDV - Center for Computer Graphics (CCG, www.ccg.pt) was founded in 1993 and established at the University of Minho in 2001 as a research, development, training and consulting entity, a private and non-profit organization, and integrated in the Portuguese Scientific System. Headquartered at the University of Minho, in the Azurém Campus in Guimarães, CCG has a young and dynamic team that consists of more than fifty employees and fifteen external researchers. It's also has support from founding members and constituents - the University of Minho and ZGDV ZentrumfürGraphischeDatenverabeitung (German Institute for Computer Graphics, Darmstadt, Germany) and twentythree members, from business and associative area, as well as participation in four companies and six trade associations.

\section{SOME CONSIDERATIONS}

Engineering education in a technology-dependent world is an issue that deserves to be widely debated by professors and institutions in the search for the best way to use technology in a way to prepare classes and experiences in order to enhance the knowledge acquisition. It is a world of instant information access, real time communication and all the gadgets available for anybody and becoming more and more affordable. The discussions are around some topics pointed out as the key issue for the development of science and technology, such as: new communication devices, global competitiveness, which leads to the urge of communication skills development, career opportunities, project management, sustainability, etc.

The discussion have been around the key strategy to provide practicing engineers ways to identify the skills, knowledge, values, and ways of thinking that engineers need to acquire for professional success and satisfaction.

It is without any doubt a global economy; skills in science, technology, engineering and math are becoming increasingly important. Governments, institutions and communities are working hard in order to provide appropriate education reframing the curriculums and make them a set of development of experiences that could attract more interest into the engineering and technology students.

Good teachers practices must be pursued and they are the best way to motivate students to understand and apply all the knowledge in practical way. In this case the good teacher needs to be prepared even in universities responsible for the final product that is the future professional ready to contribute for the betterment of humanity. So the theme of the congress is an inspirational topic for engineering and technology teachers and professionals to advocate innovative proposals for the formation of future engineer or computer scientists, etc.

It is interesting to point out the present trends in engineering education that are more related to the needs of today's geo-political and economics scenario such as: 
- new approaches to curriculum have to be designed to satisfy the new work market demand;

- engineering curriculum must be designed in terms of developing skills in technology use and development;

- $\quad$ students must acquire some aptitudes and behaviors in order to assimilate the new technology in their day by day studies;

- be prepared to be constantly challenged to try new things, use of technology in different approaches.

\section{THE XIII INTERNATIONAL CONFERENCE ON ENGINEERING AND TECHNOLOGY EDUCATION - INTERTECH'2014}

The XIII International Conference on Engineering and Technology Education - INTERTECH'2014 is organized by COPEC - Science and Education Research Council [16] and promoted by INTERTECH - International Council for Engineering and Technology Education[17] can count with the technical cooperation of the most important education and cultural organizations in the world like (in alphabetical order): AAMP (Fishing Museum Friends Society), ABENC (Brazilian Society of Civil Engineers), ABENGE (Brazilian Society for Engineering Education), AENUI (Asociación de EnseñantesUniversitarios de la Informática), ASEE (American Society for Engineering Education), ASIBEI (Ibero-American Association of Engineering Education Institutions), GCMM (Global Congress on Manufacturing and Management), IEEE-Ed.Soc. (Education Society of the Institute of Electrical and Electronics Engineers), IFEES (International Federation of Engineering Education Societies), IGIP (InternationaleGesellschaftfürIngenieurpädagogik), ISTEC (Ibero-American Science \& Technology Education Consortium), OERN (Institute of Engineers of Portugal North Region), Porto Gente (PortFolk), RBE (Brazilian Network of Engineering), RCI (RéseauCarthagèned'Ingénierie), SBA (Brazilian Automation Society), SEFI (SociétéEuropéenne pour la Formation des Ingénieurs), SHERO (Safety, Health and Environment Research Organization), SPEE (Portuguese Society for Engineering Education), SPEED (Student Platform for Engineering Education Development), WCCA (World Council on Communication and Arts) and WCSEIT (World Council on Systems Engineering and Information Technology)as well as the support of Agencies: FAPESP (State of São Paulo Research Foundation), CNPq (National Council for Scientific and Technological Development) and CAPES (Coordination for Improvement of Personnel of Superior Level).

\section{STRUCTURE OF INTERTECH'2014}

INTERTECH'2014 is an event that has been organized with the goal to provide the best environment for discussions and experience exchange among teachers, researchers and professionals of engineering and technology who work for the enhancement of education.

- Key note speakers: specialists will be speaking about their area of expertise and will answer questions of the audience;

- Round Tables and Panels: A meeting with invited specialists to debate with the audience themes that are important for engineering and technology education;

- Technical Sessions: professionals and researchers will be presenting papers of relevance, specially selected by the international committee. These papers present the top researches and experiences;

- The Open Session: It counts with the presence of congress organizers, members of the committee as well as participants and authorities of the host cities and University;

- During the event attendees can participate of cultural and social activities specially organized for the conference.

\section{PlanNing}

The planning for the organization of an event comprehends a number of activities developed in phases that requires human resources and material, which works are the result of a lot of efforts and dedication. The development of the activities has 4 phases:

- 1 st - Conception of the Project INTERTECH'2014, in this phase there were discussions about the estimate date, necessary resources, establishment of goals and the elaboration of the Project.

- 2nd - Pre-Event that involves the establishment of the necessary activities for the accomplishment of the event:

- Operational team;

- Basic Budget;

- Basic Chronogram;

- $\quad$ Services to be hired;

- Establishment of organogram.

- 3rd - Event, which is the accomplishment of the Project taking into account the realities that present at the moment. It is the congress happening with all the activities that are necessary to develop during this phase that are basically the reception of attendees, accompaniment of all the sessions.

- 4th - After the event when the congress finishes a report is made with all the information about the congress and send to the Council, to be in the databases of the organization, to the Foment Agencies and etc.

COPEC team has around 4 people working directly and exclusively to accomplish INTERTECH'2014 plus 3 others for some time, 5 days per week, 6 hours per day. During the congress more people is hired for reception and technical issues as well as transportation, feeding, cultural activities and others when they are necessary. 
COPEC team has:

- widely spread call for papers, electronically and folders;

- advertisements in international Journals;

- made and maintained the homepage in two languages English and Portuguese;

- a secretariat telephone and fax number for questions and information;

- managed the reception and reviewing process of papers;

- as well as organized the cultural and social activities of the conference.

It took twelve months of hard work and dedication.

\section{Publications}

INTERTECH'2014 publishes a collection of papers that were approved by the Technical Program Committee as well as a Book of Abstract and Program in electronic version that has all the abstracts of papers presented in the congress. Both the Book of Abstracts and the Proceedings ofINTERTECH'2014were registered at the National Library, and were attributed an ISBN number international validity. Besides, the proceedings have ISSN too because there is a online journal, named Proceedings of INTERTECH where all the papers are published.

\section{Final Comments}

Every innovative initiative has to be acknowledge and INTERTECH is thanks to the tenacity and hard work of the man who has started INTERTECH: Prof. Muthar Al-Ubaidi a professor and mentor of thousands of students and colleagues who has been the main beam in promoting Engineering and Technology Education discussions far before globalization phenomenon happened.

COPEC - Science and Education Research Council is very glad to organize the $13^{\text {th }}$ Edition of INTERTECH in Portugal mainly because it is a great opportunity for scientists and professionals to attend a congress that is already traditional and well known world wide in a great historical place such in Guimarães.

The best accomplishment of this congress is that it has become recognized internationally for its quality and large number of participants even now during hard times for world economy inserted in crises and when academic community is suffering with cuts in budgets.

The mutant and challenging engineering education community has a space for debates and discussions as well as proposal of solutions in INTERTECH congresses. It is a pleasure for its community to invite and welcome those who would like to enroll next INTERTECH edition in 2016!

\section{BIBLIOGRAPHY}

[1] Brito, C. da R.; Ciampi, M. M., Al-Ubaidi, M.INTERTECH:

Yesterday, Today and Always - 20 Years of Contributions for Engineering Education. In: International Conference on Engineering and Technology Education, 10, Peruíbe, 2008. The New
Technologies for the Engineering and Technology Education. Peruíbe: INTERTECH, 2008.p. 01-5.

[2] Brito, C. da R.; Ciampi, M. M., Al-Ubaidi, M.Engineering and Technology Education Innovating for Growth. In: International Conference on Engineering and Technology Education, 11, Ilhéus, 2010. Engineering and Technology Education Innovating for Growth.Ilhéus: INTERTECH, 2010.p. 01-5.

[3] Brito, C. da R.; Ciampi, M. M.; Vasconcelos, R.; Amaral, L., AlUbaidi, M.Engineering and Technology Education: Turning Challenges into Opportunities. In: International Conference on Engineering and Technology Education, 12, East Timor, 2012. Engineering and Technology Education: Turning Challenges into Opportunities.East Timor: INTERTECH, 2012.p. 01-6.

[4] Brito, C. da R.; Ciampi, M. M. IGIP NMC-Brazil: "Local Identity Global Awareness" - Engineering Education Today for Tomorrow. In: World Conference on Computer Science, Engineering and Technology Education, 1, Itanhaém, 2006. New Engineering to a New WorldItanhaém: WCCSETE, 2006. p. 01-3.

[5] Brito, C. da R.; Ciampi, M. M.; Taraman, K.GCMM - Manufacturing and Management for Global Prosperity. In: Global Conference on Manufacturing and Management, 8, Santos, 2006. Manufacturing and Management for Global Prosperity.Santos: GCMM, 2006.p. 01-3.

[6] Brito, C. da R.; Ciampi, M. M. IGIP: Working for the Future. In: International Conference on Engineering and Computer Education, 5, Mongaguá, 2007. The always noble mission of the education: to work for the future.Mongaguá: ICECE, 2007.p. 01-5.

[7] Brito, C. da R.; Ciampi, M. M. IGIP: from Europe to the World. In: International Conference on Engineering and Computer Education, 6, Buenos Aires, 2009. Educating Engineers for Innovation. Buenos Aires: ICECE, 2009.p. 01-4.

[8] Brito, C. da R.; Ciampi, M. M.; Vasconcelos, R.; Amaral, L. Engineering Education Inspiring the Next Generation of Engineers, 7, Guimarães, 2011. Engineering Education Inspiring the Next Generation of Engineers.Guimarães: ICECE, 2011.p. 01-4.

[9] Brito, C. da R.; Ciampi, M. M. Forming Engineers for a Growing Demand, 8, Luanda, 2013. Forming Engineers for a Growing Demand. Luanda: ICECE, 2013. p. 01-5.

[10] Brito, C. da R.; Ciampi, M. M. Forming International Engineers for the Information Society - IGIP'2011. In: IGIP International Symposium on Engineering Education, 40, Santos, 2011. Forming International Engineers for the Information Society. Santos: IGIP, 2011. p. 01-4.

[11] Brito, C. da R.; Ciampi, M. M.; Barros, V. F. A.Innovative and Reliable Information Technology for a Sustainable World. In: World Congress on System Engineering and Information Technology, 1, Porto, 2013. Innovative and Reliable Information Technology for a Sustainable World. Porto: WCSEIT, 2013. p. 01-5.

[12] http://www.cm-guimaraes.pt/PageGen.aspx

[13] http://www.guimaraesdigital.com/

[14] http://www.ccg.pt/

[15] http://www.uminho.pt/

[16] http://www.copec.org.br

[17] http://www.copec.org.br/intertech 